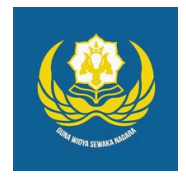

Jurnal Analogi Hukum

Journal Homepage: https://ejournal.warmadewa.ac.id/index.php/analogihukum

\title{
Pelaksanaan Kewenangan Kejaksaan Negeri Denpasar dalam Penuntutan Tindak Pidana Narkotika oleh Anak
}

\author{
Komang Ayu Sintia Dewi*, I Nyoman Putu Budiartha dan I Nyoman Gede Sugiartha \\ Universitas Warmadewa, Denpasar-Bali, Indonesia \\ *komangayuS@gmail.com
}

\begin{abstract}
How To Cite:
Dewi, K, A, S., Budiartha, I, N, P., Sugiartha, I, N, G.(2020). Pelaksanaan Kewenangan Kejaksaan Negeri Denpasar dalam Penuntutan Tindak Pidana Narkotika oleh Anak. Jurnal Analogi Hukum. 2 (3). 283-287. Doi: https://doi.org/10.22225/ah.2.3.2580.283-287

Abstract-Independent state power, especially the implementation of authority and duties in the field of prosecution is the duty of the Prosecutor as a government institution whose provisions are in accordance with Article 30 of the Republic of Indonesia Prosecutor's Law Number 16 of 2014. Handling of child crimes in conflict with the law regulated in the Criminal Justice System and different from adults are seen in quantity and quality in carrying out acts against the law, for example narcotics abuse. The formulation of the problem (1) how is the implementation of the authority of the Denpasar District Attorney in prosecuting child narcotics crimes? (2) what are the inhibiting factors for prosecuting children who commit criminal acts of narcotics at the Denpasar District Attorney's Office? The method used in this study is an empirical legal method. The results showed that it was synchronized between the regulations governing the prosecutor's authority in prosecution with the implementation of the prosecutor's authority in the Denpasar District Prosecutor's Office and the inhibiting factors of the Denpasar District Prosecutor's authority in prosecuting child narcotics crimes, namely infrastructure and facilities, awareness of the community and child in question. The countermeasures carried out by the Denpasar District Prosecutor's Office include the Greeting Prosecutor Program, School Entrance Prosecutors and the Wayan Adhyaksa application.
\end{abstract}

Keywords: Prosecutors; Children; Narcotics

\begin{abstract}
Abstrak-Kekuasaan negara yang merdeka terutama pelaksanaan kewenangan dan tugas di bidang penuntutan merupakan tugas Kejaksaan sebagai lembaga pemerintahan yang ketentuannya sesuai Pasal 30 Undang-undang Kejaksaan Republik Indonesia Nomor 16 Tahun 2014. Penanganan tindak pidana anak yang berkonflik dengan hukum diatur dalam Sistem Peradilan Pidana dan berbeda dengan orang dewasa dilihat secara kuantitas dan kualitas dalam melakukan perbuatan melawan hukum contohnya penyalahgunaan narkotika. Adapun rumusan masalah (1) bagaimanakah pelaksanaan kewenangan dari Kejaksaan Negeri Denpasar dalam penuntutan tindak pidana narkotika anak? (2) apakah faktor penghambat dari penuntutan anak yang melakukan tindak pidana narkotika di Kejaksaan Negeri Denpasar? Metode yang digunakan dalam penelitian ini adalah metode hukum empiris. Hasil penelitian menunjukkan bahwa sudah sinkron antara regulasi yang mengatur kewenangan kejaksaan dalam penuntutan dengan pelaksanaan kewenangan kejaksaan dalam penuntutan di Kejaksaan Negeri Denpasar dan faktor penghambat dari pelaksanaan kewenangan Kejaksaan Negeri Denpasar dalam penuntutan tindak pidana narkotika anak yaitu faktor prasarana dan sarana, kesadaran dari masyarakat serta dari anak yang bersangkutan. Upaya penanggulangan yang dilakukan Kejaksaan Negeri Denpasar antara lain dengan Program Jaksa Menyapa, Jaksa Masuk Sekolah serta aplikasi Wayan Adhyaksa.
\end{abstract}

Kata Kunci: Kejaksaan; Anak; Narkotika

\section{Pendahuluan}

Reformasi penegak hukum semakin gencar dilakukan oleh Pemerintah, gaung tentang pentingnya penguatan Kejaksaan secara kelembagaan semakin marak diperbincangkan di berbagai kalangan. Beragam beredar isu tentang kedudukan kejaksaan dalam sistem ketatanegaraan, penerapan dari prinsip single prosecution system, maupun konfigurasi hubungan antara fungsi penuntutan dengan subsistem peradilan pidana lainnya dibahas dalam seminar nasional, focus group discussion maupun berbagai forum akademik (Maringka, 
2017).

Lembaga pemerintahan yakni Kejaksaan Republik Indonesia melaksanakan kekuasaan negara yang merdeka dalam pelaksanaan kewenangan dan tugas dalam penuntutan, berdasarkan perundang-undang. Untuk melaksanakan wewenang dan tugasnya, Jaksa akan bertindak untuk mematuhi norma kesusilan dan keagamaan, dan menggali dari nilai dalam masyarakat seperti nilai kemanusiaan dan keadilan.

Asas lex specialis derogat legi generalis berlaku untuk perkara anak yang berbeda dengan perkara orang dewasa, yang artinya sistem peradilan pidana anak sebagai hukum khusus akan mengesampingkan aturan hukum yang bersifat umum. Data dari UNICEF sudah melaporkan kurang lebih lima ribu anak di Indonesia berhadapan dengan hukum setiap tahun, jumlahnya tidak pasti akan tetapi tiap tahun anak yang berkonflik dengan hukum terus bertambah (Fultoni, 2012).

Sistem sanksi untuk anak dalam hukum pidana dapat diperdebatkan, apalagi ketentuan yang ada di negara sedang berkembang. Hal ini didasarkan pada pemikiran bahwa hukum pidana negara di negara-negara sedang berkembang biasanya kecepatan perkembangannya tidak berbanding lurus dengan perkembangan masyarakat. Sanksi adalah suatu perbuatan yang dilakukan mengakibatkan konsekuensi logis. Berbagai bentuk sanksi misalnya sanksi moral, sanksi hukum (Sutatiek, 2013). Pelaku tindak pidana oleh anak saat ini dapat dijatuhi pidana atau tindakan hukum. Dalam konteks ini adalah Anak Nakal. Undang-undang Sistem Peradilan Pidana Anak Nomor 11 Tahun 2012 Pasal 1 angka 3 menyatakan anak yang berkonflik dengan hukum adalah anak yang telah berumur 12 tahun tetapi belum 18 tahun.

Narkoba (narkotika, psikotropika dan bahan-bahan zat adiktif lainnya) dapat membahayakan kehidupan manusia, jika dikonsumsi dengan cara yang tidak tepat, bahkan dapat menyebabkan kematian (Eleanora, 2011). Bersifat transnasional tindak Narkotika saat ini dilakukan dengan menggunakan tindakan operandi yang cerdik, teknologi modern, didukung jaringan organisasi internasional, serta banyak akan timbul korban, tidak hanya orang dewasa yang terjerat dalam gelombang hitam narkotika bahkan saat ini Anak juga tak sedikit yang terjerumus dalam dekapan hitam peredaran Narkotika, yang sangat membahayakan kehidupan masyarakat khususnya bagi Anak sebagai penerus bangsa dan negara, sehingga saat ini Indonesia termasuk Negara Darurat Narkotika, di Indonesia Narkotika di atur dalam Undang-undang Nomor 35 Tahun 2009 tentang Narkotika. Pemberlakuan sanksi pidana mati bagi bandar atau pengedar narkoba sesuai dengan undang-undang pidana negara Republik Indonesia, khususnya pada undang-undang Nomor 35 Tahun 2009 tentang Narkotika. Alasan kuat lain kenapa pidana mati tetap diberlakukan, karena pelaku bandar narkoba diduga dapat merusak secara massif karakter generasi anak bangsa menjadi pecandu narkoba yang dapat mengganggu kesehatan fisik dan mental mereka (Hasibuan, 2017).

Keberadaan Hukum di dalam masyarakat sangat diperlukan beserta lembaga penegak hukum khususnya pada lembaga Kejaksaan yang mempunyai kewenangan untuk melakukan Penuntutan terhadap tindak pidana yang dilakukan oleh seseorang karena dengan adanya peraturan hukum yang diperlukan dan dibutuhkan oleh masyarakat dapat dijadikan untuk pedoman dalam hubungan di masyarakat. Rule of law tercipta dari Hukum positif yang ada di kalangan masyarakat yang digunakan penguasa, dan mencegah timbulnya eigenrichting di dalam masyarakat.

Bagaimana pelaksanaan kewenangan Kejaksaan Negeri Denpasar dalam penuntutan tindak pidana narkotika oleh anak?

Apakah faktor penghambat dari penuntutan tidak pidana narkotika oleh anak di Kejaksaan Negeri Denpasar?

Adapun tujuan dari penelitian ini adalah:

Untuk mengetahui pelaksanaan kewenangan kejaksaan dalam tindak pidana Narkotika anak di wilayah hukum Kejaksaan Negeri Denpasar.

Untuk mengetahui faktor penghambat pihak Kejaksaan Negeri Denpasar dalam penuntutan terhadap Tindak Pidana Narkotika oleh Anak.

\section{Metode}

Setiap penelitian yang dilakukan memiliki pendekatan dan metodenya masing-masing. Berdasarkan latar belakang dan rumusan masalah di atas, penelitian ini menggunakan metode empiris. Adapun pendekatan yang digunakan dalam penulisan skripsi ini adalah sosiologi hukum. Berikut dipaparkan lebih lanjut metode penelitian yang digunakan: 
Tipe Penelitian dan Pendekatan Masalah

Berdasarkan pada perumusan masalah, maka tipe penelitian yang digunakan memakai penelitian empiris sehingga di dalam jurnal ini lebih mengkaji tentang Peranan hukum sebagai sarana pembaruan masyarakat.

\section{Sumber Data}

Penelitian ini menggunakan 2 data yaitu: Data Primer, yaitu sumber datanya diperoleh dari penelitian lapangan (field research) untuk memperoleh data yaitu di wilayah hukum Kejaksaan Negeri Denpasar. Data yang Sekunder, yaitu data yang didapat dalam kepustakaan.

Lokasi Penelitian dan Penentuan Sampel. Penelitian dilakukan di Kejaksaan Negeri Denpasar, Jalan Jendral Sudirman No. 58, Dauh Puri, Denpasar Barat, Kota Denpasar Bali 80232. Teknik penentuan sample peneliti adalah dengan teknik non probaliti sampling khususnya dengan menggunakan teknik purposive.

\section{Teknik Pengumpulan Data}

Teknik pengumpulan data yang mempergunakan teknik studi dokumen dan teknik wawancara.

\section{Analisis Data}

Menggunakan pengolahan dan analisis data dari lapangan maupun dari kepustakaan dan diolah kualitatif kemudian disajikan dalam bentuk deskriptif kualitatif, sehingga akan dapat diperoleh suatu suatu kesimpulan dan kebenaran.

\section{Hasil Penelitian Dan Pembahasan}

\section{Pelaksanaan Kewenangan Kejaksaan Negeri Denpasar Dalam Penuntutan Tindak Pidana Narkotika Oleh Anak}

Kewenangan Kejaksaan dalam tahap penuntutan terhadap anak yang berkonflik dengan hukum, khususnya perkara tindak pidana narkotika. Berdasarkan hasil penelitian, kewajiban dari Kejaksaan Republik Indonesia diatur Undang-undang tentang Kejaksaan Republik Indonesia Nomor 16 Tahun 2004 Pasal 2 ayat (1), 41 ayat (1) UU Sistem Peradilan Pidana Anak jelas penuntutan terhadap anak dilakukan oleh Penuntut Umum, Pasal 42 ayat (1) UU tentang Sistem Peradilan Pidana Anak yakni Penuntut Umum wajib mengupayakan upaya diversi untuk anak yang berhadapan dengan hukum. Pasal 14 KUHAP mengenai Kewenangan Kejaksaan yang menerima dan memeriksa berkas perkara penyidikan dari penyidik dengan wajib memperhatikan ketentuan Pasal 110 ayat (3) (4). Pasal 30 mengatur tentang Kewenangan Kejaksaan, di dalam bidang pidana memiliki wewenang melakukan penuntutan. Pasal 140 ayat (2) huruf a KUHAP mengatur tentang Hak Kejaksaan yang bisa menghentikan penuntutan perkara demi hukum dengan mempertimbangan apabila bukti-bukti tidak cukup. Pasal 8 ayat (3) KUHAP jo Pasal 110 (1) KUHAP memuat tentang mekanisme kerja Kejaksaan, pelaksanaan di lapangan aturan-aturan ataupun nrma hukum yang menjadi pedoman dalam melaksanan kewenangan oleh pihak Kejaksaan Negeri Denpasar sampai saat ini sudah sangat sinkron, dapat dilihat dari seluruh aparat penegak hukum yang terkait dalam penegakan hukum tindak pidana yang dilakukan oleh anak yang berhadapan dengan hukum dalam hal ini dalam tindak pidana narkotika, antara peraturan saling berkaitan sehingga saling menguatkan dan mendukung dalam pelaksanaan penuntutan jaksa penuntut umum Kejaksaan Negeri Denpasar dalam menjalankan kewenangannya di bidang penuntutan, hak yang dimiliki seorang jaksa dalam bidang penuntutan tersebut akan mendukung tercapainya Pelaksanaan Kewengan di Kejaksaan Negeri Denpasar dalam tahap penuntutan terutama dalam tahap penuntutan terhadap tindak pidana narkotika anak akan optimal dalam pekerjaannya untuk memberikan keadilan, keamanan serta mengayomi masyarakat, khususnya bagi anak dengan selalu mendahulukan kepentingan dari anak dalam proses perkara dari anak.

Pelaksanaan kewenangan Kejaksaan Negeri Denpasar terhadap tindak pidana Narkotika oleh anak didalam wilayah hukum Kejaksaan Negeri Denpasar, memiliki Jaksa Khusus yang menangangi perkara anak yang berhadapan dengan hukum sesuai dengan SK yang dikeluarkan oleh pimpinan yang dalam hal ini adalah Kepala Kejaksaan Negeri Denpasar. Data perkara tindak pidana anak dari tahun 2015 sampai dengan tahun 2018 ini sebanyak 53 perkara anak yang menjadi subjek hukum serta objek hukum dari tindak pidana, 11 diantaranya merupakan Anak yang berhadapan dengan hukum dengan perkara tindak pidana narkotika oleh anak. Prosedur penanganan perkara anak yang berhadapan dengan hukum tersebut berkaitan bersinergi penegakan hukum. Sistem Peradilan Pidana Anak memberikan perlakuan khusus serta 
perlindungan untuk menjaga kepentingan anak serta mengetahui latar belakang kehidupan dari anak untuk pertimbangan menghasilkan tuntutan dari Majelis Hakim. Pelaksanaannya sudah sesuai dengan yang diamanatkan oleh Peraturan Perundangundangan yang berlaku proses Penuntutan bagi anak nakal dalam pelaksanaan di Kejaksaan Negeri Denpasar sudah berjalan optimal dengan menerapkan pendekatan restoratif serta selalu mengupayakan upaya diversi bagi anak yang berhadapan dengan hukum.

\section{Faktor-faktor Penghambat Penuntutan Tindak Pidana Narkotika oleh Anak di Kejaksaan Negeri Denpasar}

Pembahasan mengenai faktor penghambat kewenangan penuntutan Kejaksaan Negeri Denpasar dalam penuntutan tindak pidana narkotika anak, dalam penelitian ini menggunakan teori efektivitas hukum. Semakin mendekati sasaran maka tinggi efektivitasnya (P.Siagian, 2002). Keberhasilan dari hukum penggunaan yaitu keberhasilan untuk mengimplementasikan hukum itu sendiri dalam kehidupan masyarakat. Secara sosiologis banyak faktor yang mempengaruhi efektifitas penegakan hukum. Menurut Soerjono Soekanto (Soekanto, 1983) masalah dari penegak hukum terlihat dari faktor yang mempengaruhinya, sebagai berikut: faktor hukumnya sendiri, penegak hukum, prasarana dan sarana, faktor masyarakat, kebudayaan. Berdasarkan hasil penelitian faktor penghambat dari penelitian ini adalah sarana dan prasarana, faktor kesadaran hukum masyarakat dan Faktor dari dalam diri anak yang berhadapan dengan hukum. Problematika klasik yang menjadi faktor penghambat penuntutan ataupun proses penyelesaian perkara anak yang melakukan tindak pidana narkotika yaitu, rumah tahanan dalam hal sarana dan prasarana untuk mendukung keberlangsungan penegakan hukum yang dilakukan oleh Kejaksaan Negeri Denpasar sendiri, yang mana Lembaga Permasyarakatan Gianyar untuk Anak yang berhadapan dengan hukum tersebut letaknya di Kabupaten Karangasem yang jarak tempuhnya sangat jauh dari Pengadilan Negeri Denpasar.
Berkaitan budaya hukum saat ini sangat bergantung dengan perilaku hukum masyarakat pada umumnya. Dalam elemen ini gejala yang biasanya timbul yaitu degradasi budaya hukum di lingkungan masyarakat yang masih ada kaitannya dengan anak yang berhadapan dengan hukum biasanya tanda-tanda yang muncul dari aspek ini melainkan meningkatnya apatisme dari kalangan masyarakat terhadap penegakan hukum yang dilakukan oleh aparat penegak hukum, seiring menurunnya tingkat apresiasi dari masyarakat sendiri, baik pada substansi hukum yang terkait maupun kepada struktur hukum yang terlibat di dalam proses penegakan hukum. Proses pelaksanaan kewenangan penuntutan terhadap tindak pidana narkotika oleh anak, faktor yang juga menjadi penghambat dari pelaksanaannya yaitu dari dalam diri si anak, karena kondisi psikis si anak masih belum cukup matang untuk memberikan kesaksian ataupun keterangan dalam proses pemeriksaan. Anak yang usianya masih belia memiliki pemikiran yang berubahubah sehingga keterangan yang dberikan kepada pihak Penuntut Umum menjadi ambigu dan acapkali berubah-ubah dalam proses pemeriksaannya, sehingga meyebabkan keterlambatan waktu pemeriksaan dan keterangan yang diberikan seringkali berubah-ubah setiap pemeriksaan. Kejaksaan Negeri Denpasar beberapa tahun terakhir ini sudah gencar mengadakan kegiatan penyuluhan hukum ke sekolah-sekolah wilayah hukum Kejaksaan Negeri Denpasar dengan melakukan giat yang bernama "Jaksa Masuk Sekolah" atau JMS, dengan berkembangnya teknologi di masyarakat yang notabenenya saat ini lebih banyak menggunakan gadget, sehingga Kejaksaan Negeri Denpasar mengikuti perkembangan teknologi dengan sebuah aplikasi yang bisa diakses oleh smartphone, aplikasi yang bernama "Wayan Adhyaksa" ini berfungsi untuk menyalurkan aspirasi masyarakat secara umum, baik pengaduan, kritik serta saran yang ingin disampaikan kepada instansi kami Kejaksaan Negeri Denpasar agar meningkatkan kinerja kami dalam pelayanan hukum kepada masyarakat, Kejaksaan Negeri Denpasar juga melaksankan kegiatan "Jaksa Menyapa" yang bekerja sama dengan Radio Publik 
Kota Denpasar (RPKD) yang bertujuan untuk memberikan wawasan tentang hukum bagi masyarakat luas agar tindak melakukan perbuatan yang melawan hukum.

\section{Simpulan}

Pelaksanaan Kewenangan Kejaksaan Negeri Denpasar dalam penuntutan tindak pidana narkotika anak sudah sinkron antara Undang-undang yang mengatur dengan pelaksanaannya di lapangan dilihat dari variabel kewajiban, kewenangan, hak serta mekanismenya. Sesuai dengan Undang-undang Nomor 11 tahun 2012 tentang Sistem Peradilan Pidana Anak, Undang-undang Nomor 16 Tahun 2004 tentang Kejaksaan Republik Indonesia, Undang-undang Nomor 35 Tahun 2009 tentang Narkotika.

Faktor penghambat dari penuntutan dalam tindak pidana narkotika oleh anak di Kejaksaan Negeri Denpasar yaitu: faktor sarana dan prasarana, faktor kesadaran masyarakat serta faktor anak yang berhadaan dengan hukum. Upaya yang dilakukan Kejaksaan Negeri Denpasar dalam meminimalisir faktor penghambat tersebut yaitu dengan berbagai kegiatan diantaranya: Jaksa Masuk Sekolah, Program Wayan Adhyaksa, Program Jaksa Menyapa melalui Radio Publik Kota Denpasar (RKPD).

\section{Daftar Bacaan}

Eleanora, F. N. (2011). Bahaya Penyalahgunaan Narkoba Serta Usaha Pencegahan Dan Penanggulangannya (Suatu Tinjauan Teoritis). Jurnal Hukum, 25(1). Retrieved from http:// jurnal.unissula.ac.id/index.php/ jurnalhukum/article/view/203

Fultoni. (2012). Anak Berkonflik dengan Hukum. Jakarta. Retrieved from The Indonesian Legal Resource Center (ILRC)

Hasibuan, A. A. (2017). Narkoba dan Penanggulangannya. STUDIA DIDAKTIKA: Jurnal Ilmiah Bidang Pendidikan, 11(1). Retrieved from http://jurnal.uinbanten.ac.id/index.php/ studiadidaktika/article/ download/517/445/

Maringka, J. (2017). Reformasi Kejaksaan Dalam Sistem Hukum Nasional, (Sambutan Jaksa Agung Republik Indonesia). Jakarta Timur: Sinar
Grafika.

P.Siagian, S. (2002). Kiat Meningkatkan Produktivitas Kerja. Jakarta: Rineka Cipta.

Soekanto, S. (1983). Faktor-faktor Yang Mempengaruhi Penegakan Hukum. Jakarta: Rajawali.

Sutatiek, S. (2013). Rekontruksi System Sanksi Dalam Hukum Pidana Anak Di Indonesia. Yoyakarta: Aswaja Pressindo. 